\title{
Effect of Biliary Drainage on the Toxicity and Toxicokinetics of Amanita exitialis in Beagles
}

\author{
Jian Sun ${ }^{1,2}{ }^{10}$, Yu-Tao Zhang ${ }^{1}$, Yu-Min Niu ${ }^{3}$, Hai-Jiao Li ${ }^{1}$, Yu Yin ${ }^{1}$, Yi-Zhe Zhang ${ }^{1}$, \\ Pei-Bin Ma ${ }^{1}$, Jing Zhou ${ }^{1}$, Jun-Jia Lu ${ }^{1}$, Hong-Shun Zhang ${ }^{1, *}$ and Cheng-Ye Sun ${ }^{1, *}$ \\ 1 National Institute of Occupational Health and Poison Control, Chinese Centre for Disease Control and \\ Prevention, Beijing 100050, China; sunjian2019652@163.com (J.S.); zhangyutao0708@163.com (Y.-T.Z.); \\ lihaijiao715@163.com (H.-J.L.); yymssyn@126.com (Y.Y.); zyz97@263.net (Y.-Z.Z.); \\ mapb@niohp.chinacdc.cn (P.-B.M.); zhoujing@niohp.chinacdc.cn (J.Z.); lujunjia1990@163.com (J.-J.L.) \\ 2 Institute of Public Health and Management, Ningxia Medical University, Yinchuan 750004, China \\ 3 Beijing Key Laboratory of Diagnostic and Traceability Technologies for Food Poisoning, \\ Beijing Center for Disease Control and Prevention, Beijing 100013, China; nym0542010@163.com \\ * Correspondence: lswlpd@yeah.net (H.-S.Z.); suncy@chinacdc.cn (C.-Y.S.); Tel.: +86-010-8313-2045 (H.-S.Z.); \\ $+86-010-8313-2660$ (C.-Y.S.)
}

Received: 24 April 2018; Accepted: 22 May 2018; Published: 25 May 2018

\begin{abstract}
Amatoxin poisoning induces delayed-onset acute liver failure, which are responsible for more than $90 \%$ of deaths in mushroom poisoning. It has been postulated from animal and human studies that biliary drainage interrupting enterohepatic amatoxin circulation may affect amatoxin poisoning. Dogs were randomly divided into four groups of six animals each. In $20 \mathrm{mg} / \mathrm{kg}$ and $60 \mathrm{mg} / \mathrm{kg}$ with biliary drainage groups, after accepting bile drainage operation, beagles were fed Amanita exitialis powder ( 20 or $60 \mathrm{mg} / \mathrm{kg}$ ) in starch capsules. In control and bile drainage groups, the beagle dogs were fed with empty capsules. They were assessed for toxicity signs, biochemical and pathological changes, and peptide toxins in plasma, urine and bile. The data were directly compared with those from our published studies on Amanita exitialis-exposed beagles without biliary drainage. Amatoxins were rapidly absorbed and eliminated from plasma after Amanita exitialis ingestion. Amatoxins in 0-1-day urine accounted for more than $90 \%$ of the total urine excretion, and amatoxins in bile accounted for less than $20 \%$ of the total urine and bile excretion. The dogs with biliary drainage showed less severe toxicity signs and biochemical and pathological changes and much lower internal exposure than dogs without biliary drainage. Biliary drainage caused a more than $70 \%$ reduction in intestinal amatoxin absorption and could reduce amatoxin absorption from the gastrointestinal tract.
\end{abstract}

Keywords: Amanita exitialis; amatoxins; beagles; bile drainage; urine

Key Contribution: We established a long-term bile drainage model with beagles in a normal state. This model can be applied to study bile secretion and components in bile-related diseases including amatoxin poisoning. Biliary drainage produced a more than $70 \%$ reduction in intestinal amatoxin absorption in beagle dogs. This indicated that biliary drainage may also reduce amatoxin absorption in human.

\section{Introduction}

According to the Chinese Management Information System of Public Health Emergency, 3701 patients and 786 deaths were reported in 576 incidents of mushroom poisoning from 2004 to 2014 [1]. Mushroom poisoning is considered the main cause of food poisoning-related mortality in China. The section of Phalloideae in Amanita genus has been responsible for at least $70 \%$ of deaths from mushroom 
poisoning incidents in China [2], and the hepatotoxic effects of amatoxins and phallotoxins from Amanita species [3] are well known [4]. Amatoxins bind to the Retinol Binding Protein 1 (RBP1) of RNA polymerase II to form a complex, and thereby progressively decrease the mRNA content, which causes inhibition of protein synthesis and eventually results in cell death [5]. Phallotoxins and virotoxins firmly bind to F-actin. It has been postulated that cross-linking effect by bifunctionality of the phallotoxin molecules or allostery of enforcing the coherence between actin units must play an important role in their stabilizing action [6]. Lesions are found particularly in the liver [7].

At 6-24 $\mathrm{h}$ after ingestion of amatoxin-containing mushroom, patients present gastrointestinal symptoms including nausea, vomiting, abdominal pain, and diarrhea [8,9]. At $36-48 \mathrm{~h}$ after ingestion, biochemical signs of liver damage in the patients increase, especially in liver transaminase and bilirubin levels. Three to four days after ingestion, patients may develop jaundice, slight enlargement and tenderness of the liver. Acute hepatic failure, such as hyperbilirubinemia, coagulation disorders, bleeding, and encephalopathy, may develop in the following days. Death may occur within 3-7 days after mushroom ingestion, while surviving patients recover within 14-21 days [3,10,11]. Based on animal studies, it has been postulated that intravenously administered amanitin is excreted in the bile fluid $[12,13]$. Biliary amanitin excretion prolongs its presence in enterohepatic and systemic circulation because of intestinal reuptake. This mechanism could significantly influence the clinical course of amatoxins poisoning. Based on this theory, interruption of enterohepatic circulation has become an alternative part of detoxification methods. Recently, endoscopic nasobiliary drainage was performed in a patient who ingested Amanita bisporigera. A total of $2.5 \mathrm{mg}$ of amatoxin was removed through bile fluid on Day 2 after ingestion; however, the relevance between bile drainage and clinical outcome remained unclear [14]. Further, amatoxin kinetics in human poisoning cases remain to be elucidated because of delayed clinical presentations of most intoxicated patients.

In previous studies, the radioactivity of labeled amatoxins in the serum of dogs or pigs was determined after an intravenous injection of amatoxins; bile was collected and measured using tubes tied to the bile duct under general anesthesia [13,15]. More than $80 \%$ of $14 \mathrm{C}$-methyl- $\gamma$-amanitin (14C-A) was eliminated in the urine, with less than $10 \%$ in the bile [15]. Different toxin exposure patterns might result in different toxicokinetic data. 14C-A and 3H-O-methyl-dehydroxymethyl- $\alpha$-amanitin (3H-A) were used for toxicokinetic studies in the animals; the animals were under general anesthesia during the experiments. The bile and urine excretion data obtained were different from those of animals that orally ingested $\alpha$-amanitin and $\gamma$-amanitin.

In our previous study, the toxicity of Amanita exitialis and the toxicokinetics of its constituent peptide toxins were determined in dogs that were orally administered 20 and $60 \mathrm{mg} / \mathrm{kg}$ Amanita exitialis $[16,17]$. This model induced by Amanita exitialis is consistent with clinical pathophysiological process of acute toxic liver failure induced by mushrooms containing peptide toxins [17]. In the present study, we established a long-term bile drainage model to evaluate biliary and urinary amatoxin excretion in 20 and $60 \mathrm{mg} / \mathrm{kg}$ Amanita exitialis-exposed beagles. Furthermore, we studied the effect of biliary drainage on the toxicity and toxicokinetics of Amanita exitialis by directly comparing the data obtained with those from our published studies on beagles with the exposure of the same dose of Amanita exitialis without bile drainage.

\section{Results}

\subsection{Peptide Toxins in Amanita exitialis}

The total and average concentrations of the four peptide toxins in the mushroom are shown in Table 1. The amount of peptide toxins from Amanita exitialis ingested in different experimental groups is presented in Table S1. 
Table 1. Peptide toxin concentrations in Amanita exitialis ( $\mathrm{mg} / \mathrm{kg}$ dry weight).

\begin{tabular}{cccccccc}
\hline $\begin{array}{c}\text { Peptide } \\
\text { Toxin }\end{array}$ & \multicolumn{9}{c}{ Toxin Concentration $(\mathbf{m g} / \mathbf{k g})$} & & Mean & $\begin{array}{c}\text { Standard } \\
\text { Deviation (SD) }\end{array}$ \\
\cline { 2 - 8 } & $\mathbf{1}$ & $\mathbf{2}$ & $\mathbf{3}$ & $\mathbf{4}$ & $\mathbf{5}$ & $\mathbf{( m g / k g )}$ & $\mathbf{( m g / k g )}$ \\
\hline$\alpha$-amanitin & 1934.6 & 1996.8 & 1891.4 & 2060 & 1947.8 & 1966.1 & 64.6 \\
$\beta$-amanitin & 992.6 & 995.2 & 857.4 & 902.9 & 827.2 & 915.1 & 76.9 \\
$\gamma$-amanitin & 8.6 & 8.5 & 8.6 & 8.2 & 8.7 & 8.5 & 0.2 \\
phallacidin & 618.6 & 636.1 & 575.8 & 672.7 & 508.2 & 602.3 & 63.1 \\
Total & 3554.4 & 3636.6 & 3333.2 & 3643.8 & 3291.9 & 3492 & 168.2 \\
\hline
\end{tabular}

\subsection{Signs of Toxicity}

The dogs were clinically back to normal on Day 6 after accepting biliary drainage operation. After exposure, no changes were noted in the control, biliary drainage, and $20 \mathrm{mg} / \mathrm{kg}$ with biliary drainage groups. However, vomiting, diarrhea, and a loss of appetite were observed at $12-48 \mathrm{~h}$ in the $60 \mathrm{mg} / \mathrm{kg}$ with biliary drainage group. No animal died during the experiment (Table 2).

Table 2. Signs of toxicity and death in beagles following ingestion of Amanita exitialis.

\begin{tabular}{ccccc}
\hline \multirow{2}{*}{ Toxic Signs } & \multicolumn{2}{c}{ Number of Dogs (\%) } & \multicolumn{2}{c}{ Time from Ingestion to Onset (h) } \\
\cline { 2 - 5 } & $\begin{array}{c}\mathbf{2 0} \mathbf{~ m g / k g} \text { with Biliary } \\
\text { Drainage Group }\end{array}$ & $\begin{array}{c}\mathbf{6 0} \mathbf{~ m g / k g ~ w i t h ~ B i l i a r y ~} \\
\text { Drainage Group }\end{array}$ & $\begin{array}{c}\mathbf{2 0} \mathbf{~ m g / k g ~ w i t h ~ B i l l a r y ~} \\
\text { Drainage Group }\end{array}$ & $\begin{array}{c}\mathbf{6 0} \mathbf{~ m g / k g ~ w i t h ~ B i l l a r y ~} \\
\text { Drainage Group }\end{array}$ \\
\hline Loss of appetite & $0(0 \%)$ & $3(50 \%)$ & - & $12-48$ \\
Vomiting & $0(0 \%)$ & $3(50 \%)$ & - & $12-24$ \\
Diarrhea & $0(0 \%)$ & $3(50 \%)$ & - & $12-24$ \\
Weakness & $0(0 \%)$ & $0(0 \%)$ & - & - \\
Hematemesis & $0(0 \%)$ & $0(0 \%)$ & - & - \\
Hematochezia & $0(0 \%)$ & $0(0 \%)$ & - & - \\
Death & $0(0 \%)$ & $0(0 \%)$ & - & - \\
\hline
\end{tabular}

\subsection{Blood Biochemistry Analysis}

Alanine transaminase (ALT), aspartate aminotransferase (AST), and alkaline phosphatase (ALP) levels slightly increased and then normalized at Day 7 after the surgery. Total bilirubin (TBIL), direct bilirubin (DBIL), prothrombin time (PT), activated partial thromboplastin time (APTT), the international normalized ratio (INR), creatinine, and blood urea nitrogen (BUN) were normal after the surgery (Table S2).

In the control and biliary drainage groups, ALT, AST, TBIL, DBIL, ALP, PT, APTT, INR, creatinine, and BUN were in the normal range (Figures 1 and 2). In the $20 \mathrm{mg} / \mathrm{kg}$ with biliary drainage group, ALT and AST levels, PT, and INR slightly increased and then normalized at Day 7 after Amanita exitialis ingestion. The peak ALT, AST and PT levels were $34.5 \mathrm{U} / \mathrm{L}, 13.4 \mathrm{U} / \mathrm{L}$, and $8.4 \mathrm{~s}$, respectively. During the experiment, TBIL, DBIL, ALP, and APTT were in the normal range (Figures 1 and 2).

In the $60 \mathrm{mg} / \mathrm{kg}$ with biliary drainage group, ALT, AST, TBIL, DBIL, and ALP levels along with PT, APTT, and INR began to increase at Day 1 after Amanita exitialis ingestion. Peak ALT, AST, PT, APTT, and INR values were observed on Day 1.5 and were $147.3 \mathrm{U} / \mathrm{L}, 47.6 \mathrm{U} / \mathrm{L}, 9.6 \mathrm{~s}, 12.1 \mathrm{~s}$, and 1.2, respectively. Peak TBIL and DBIL levels $(8.5 \mu \mathrm{mol} / \mathrm{L}$ and $5.3 \mu \mathrm{mol} / \mathrm{L}$, respectively) were observed on Day 2. The peak ALP levels (201.2 U/L) was observed at Day 3 after Amanita exitialis ingestion. After reaching their peaks, these values began to decline and normalized at Day 21 after Amanita exitialis ingestion (Figure 1). Creatinine and BUN values were normal during the experiment in both dose groups. 

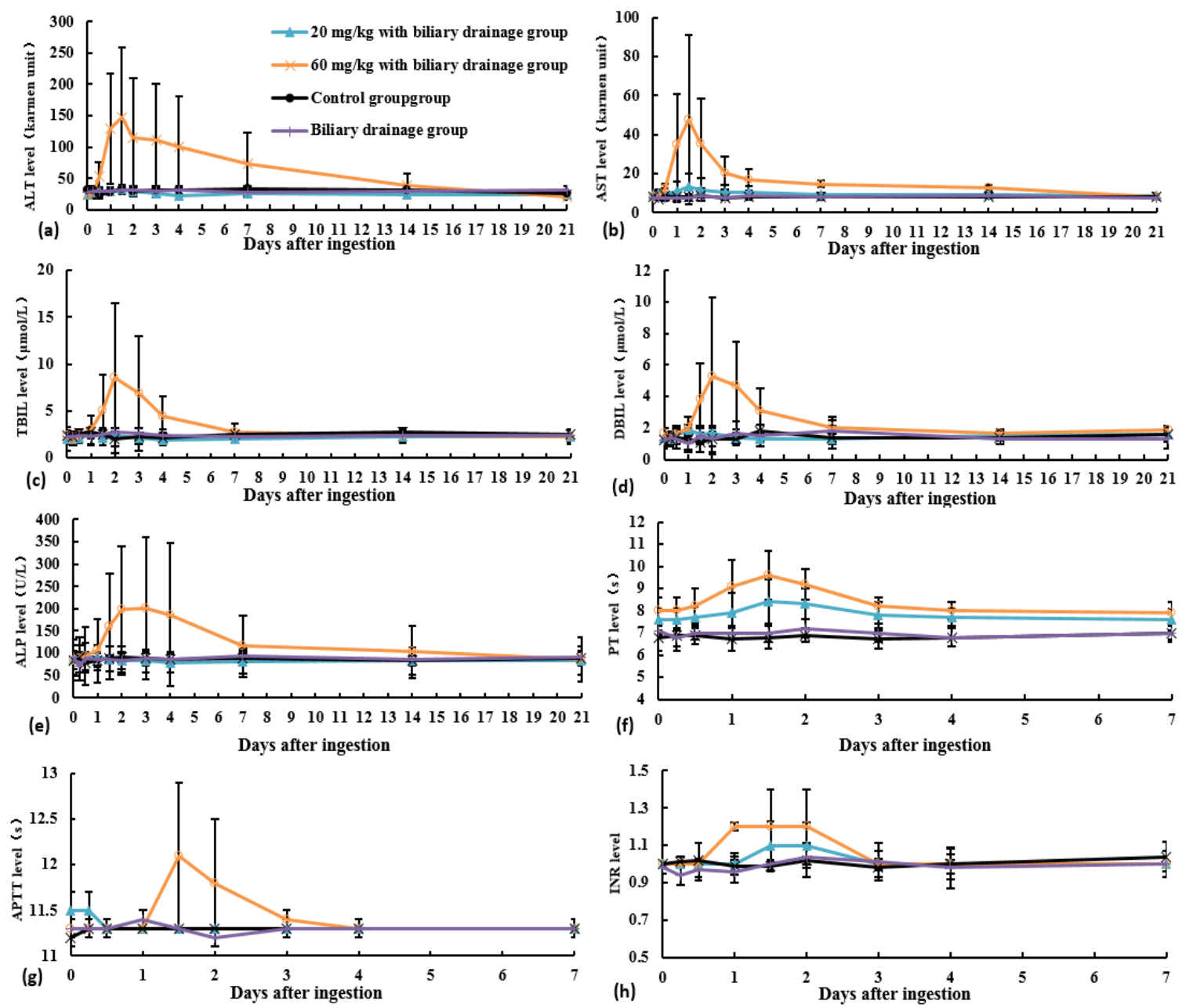

Figure 1. Blood chemistry profiles of beagles in different experimental groups: (a) ALT level; (b) AST level; (c) TBIL level; (d) DBIL level; (e) ALP level; (f) PT level; (g) APTT level; and (h) INR level.

\subsection{Histopathological Examination}

With an overdose of sodium pentobarbital, one beagle from each group was euthanized on the third day after ingestion of Amanita exitialis. Necropsy was performed and liver tissues were taken for histopathological examination. A general pathological examination of the liver showed that the color was reddish-brown and the surface was smooth (Figure S1). The hepatic tissue structure was normal, and the hepatic lobules structure was clear. A microscopic examination of the hepatic tissue revealed no obvious hepatocellular necrosis, red blood cells, inflammatory cell infiltration, or fibrous hyperplasia (Figures S2 and S3). No obvious lesions were found in the kidney, heart, lung, stomach, urinary bladder, spleen, small intestine, colon, or pancreas.

\subsection{Peptide Toxins in the Blood}

The dynamic changes of the peptide toxins in the 20 and $60 \mathrm{mg} / \mathrm{kg}$ with biliary drainage groups are shown in Figure 2. The detection rate of peptide toxins in the blood of the beagles is shown in Table S3. The calculated toxicokinetic parameters are shown in Table 3.

AUC, and $C_{\max }$ values in the $60 \mathrm{mg} / \mathrm{kg}$ with biliary drainage group were statistically higher than these values in the $20 \mathrm{mg} / \mathrm{kg}$ with biliary drainage group. Furthermore, there were no significant differences in $\mathrm{T}_{1 / 2}, \mathrm{~T}_{\max }$, clearance $(\mathrm{CL} / \mathrm{F}), \mathrm{V}_{\mathrm{Z}} / \mathrm{F}$, and mean residence time (MRT) values between the two groups. In the $20 \mathrm{mg} / \mathrm{kg}$ with biliary drainage group, there was no statistically significant 
difference in any of the toxicokinetic parameters between $\alpha$-amanitin and $\beta$-amanitin. However, in the $60 \mathrm{mg} / \mathrm{kg}$ with biliary drainage group, AUC and $C_{\max }$ values for $\alpha$-amanitin were statistically higher than these values for $\beta$-amanitin. Furthermore, except for the $\mathrm{T}_{\max }$ value, other toxicokinetic parameters for phallacidin were significantly $(p \leq 0.05)$ different from the respective values for $\alpha$-and $\beta$-amanitin.
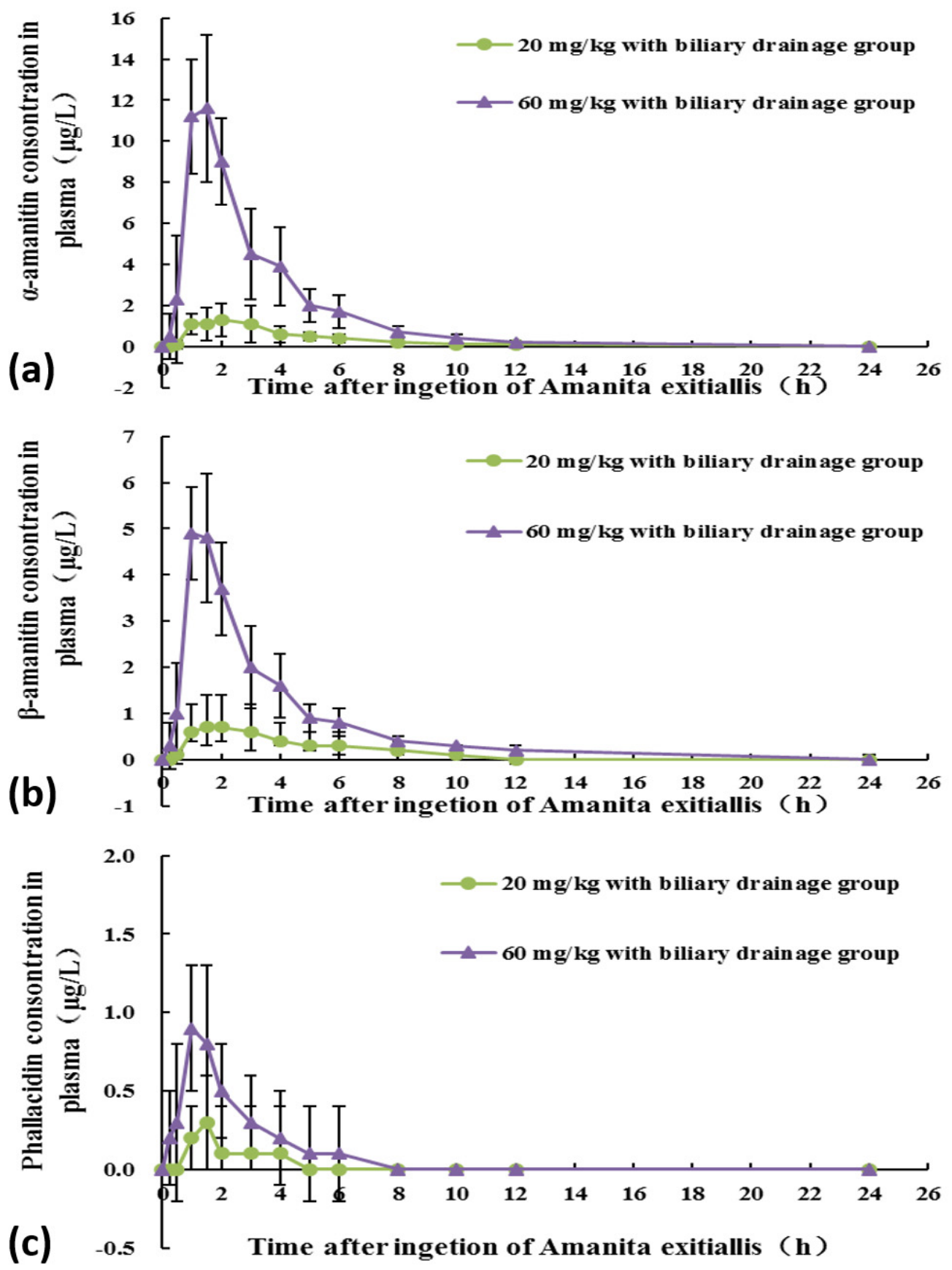

Figure 2. Dynamic changes of peptide toxins in the blood of beagles in different experimental group: (a) $\alpha$-amanitin levels; (b) $\beta$-amanitin levels; and (c) phallacidin levels. 
Table 3. Toxicokinetic parameters for peptide toxins of beagles in different experimental groups

\begin{tabular}{|c|c|c|c|c|c|c|}
\hline \multirow[b]{2}{*}{ Parameter } & \multicolumn{2}{|c|}{$\alpha$-Amanitin } & \multicolumn{2}{|c|}{$\beta$-Amanitin } & \multicolumn{2}{|c|}{ Phallacidin } \\
\hline & $\begin{array}{c}20 \mathrm{mg} / \mathrm{kg} \\
\text { with Biliary } \\
\text { Drainage } \\
\text { Group }\end{array}$ & $\begin{array}{c}60 \mathrm{mg} / \mathrm{kg} \text { with } \\
\text { Biliary } \\
\text { Drainage } \\
\text { Group }\end{array}$ & $\begin{array}{c}20 \mathrm{mg} / \mathrm{kg} \\
\text { with Biliary } \\
\text { Drainage } \\
\text { Group }\end{array}$ & $\begin{array}{c}60 \mathrm{mg} / \mathrm{kg} \text { with } \\
\text { Biliary } \\
\text { Drainage } \\
\text { Group }\end{array}$ & $\begin{array}{c}20 \mathrm{mg} / \mathrm{kg} \\
\text { with Biliary } \\
\text { Drainage } \\
\text { Group }\end{array}$ & $\begin{array}{c}60 \mathrm{mg} / \mathrm{kg} \text { with } \\
\text { Biliary } \\
\text { Drainage } \\
\text { Group }\end{array}$ \\
\hline $\mathrm{T} 1 / 2$ (h) & $1.08 \pm 0.76$ & $1.2 \pm 0.58$ & $1.29 \pm 1.07$ & $1.54 \pm 0.71$ & - & $0.62 \pm 0.32^{b, *}$ \\
\hline $\begin{array}{l}\text { AUC }(0-\infty) \\
(\mu \mathrm{g} / \mathrm{L} \times \mathrm{h})\end{array}$ & $5.36 \pm 3.17$ & $31.99 \pm 9.65^{a, *}$ & $3.24 \pm 1.49$ & $15.75 \pm 4.27^{\mathrm{a}, \mathrm{b}}$ & - & $2.08 \pm 2.06^{\mathrm{b}, *}$ \\
\hline $\begin{array}{l}\text { Dose normalized } \\
\text { AUC }(0-\infty)\end{array}$ & $138.9 \pm 82.1$ & $238.2 \pm 83.9$ & $179 \pm 82.4$ & $222.3 \pm 79.2$ & - & $60.5 \pm 60.2^{b, *}$ \\
\hline $\mathrm{C}_{\max }(\mu \mathrm{g} / \mathrm{L})$ & $1.73 \pm 0.58$ & $12.25 \pm 3.54^{\mathrm{a}, *}$ & $0.85 \pm 0.33$ & $5.18 \pm 1.32^{a, b}$ & - & $0.85 \pm 0.37^{b, *}$ \\
\hline $\begin{array}{c}\text { Dose normalized } \\
\mathrm{C}_{\max }\end{array}$ & $44 \pm 15.1$ & $86.1 \pm 30.8$ & $57 \pm 18.3$ & $96 \pm 24.4$ & - & $24.8 \pm 10.8^{\mathrm{b}, *}$ \\
\hline $\mathrm{T}_{\max }(\mathrm{h})$ & $1.38 \pm 0.48$ & $1.13 \pm 0.25$ & $1.63 \pm 0.48$ & $1.25 \pm 0.29$ & - & $1.38 \pm 0.25$ \\
\hline $\mathrm{CL} / \mathrm{F}(\mathrm{L} / \mathrm{h} / \mathrm{kg})$ & $0.85 \pm 0.43$ & $0.36 \pm 0.11$ & $0.64 \pm 0.42$ & $0.33 \pm 0.09$ & - & $1.1 \pm 0.86^{\mathrm{b}, *}$ \\
\hline $\mathrm{V}_{\mathrm{z}} / \mathrm{F}(\mathrm{L} / \mathrm{kg})$ & $1.07 \pm 0.31$ & $0.68 \pm 0.48$ & $0.78 \pm 0.63$ & $1.38 \pm 0.59$ & - & $1.77 \pm 0.57^{b, *}$ \\
\hline MRT $(0-\infty)(h)$ & $3.55 \pm 0.8$ & $2.87 \pm 0.43$ & $3.83 \pm 1.02$ & $3.89 \pm 0.46$ & - & $1.95 \pm 0.73^{b, *}$ \\
\hline
\end{tabular}

We could not calculate the toxicokinetic parameters because phallacidin was not detected in serum in the $20 \mathrm{mg} / \mathrm{kg}$ with biliary drainage group. ${ }^{a}$ indicates $p \leq 0.05$ when compared to the same toxin in the $20 \mathrm{mg} / \mathrm{kg}$ with biliary drainage group. ${ }^{\mathrm{b}}$ indicates $p \leq 0.05$ when compared to $\alpha$-amanitin in the same experimental group. ${ }^{*}$ indicates $p \leq 0.05$ when compared to $\beta$-amanitin in the same experimental group.

\subsection{Peptide Toxins in the Urine}

The urine volume of the experimental groups is presented in Figure S4a. In the $20 \mathrm{mg} / \mathrm{kg}$ with biliary drainage group, $\alpha$-amanitin, $\beta$-amanitin, and phallacidin were detected within two days. In the $60 \mathrm{mg} / \mathrm{kg}$ with biliary drainage group, $\alpha$-amanitin and phallacidin were detected within three days, and $\beta$-amanitin was detected within two days (Table S4). The detection rate of peptide toxins in the urine is presented in Table S5. In the $20 \mathrm{mg} / \mathrm{kg}$ with biliary drainage group, the accumulated amounts of $\alpha$-amanitin, $\beta$-amanitin, and phallacidin were $0.0151,0.0055$, and $0.0014 \mathrm{mg}$, respectively. In the $60 \mathrm{mg} / \mathrm{kg}$ with biliary drainage group, the corresponding accumulated amounts were $0.0222,0.0068$, and $0.0025 \mathrm{mg}$. In both the 20 and $60 \mathrm{mg} / \mathrm{kg}$ with biliary drainage groups, more than $90 \%$ of the total urine excretion of $\alpha$-amanitin and $\beta$-amanitin occurred on Days $0-1$. More than $90 \%$ of the total urine excretion of phallacidin occurred on Days $0-1$ in the $20 \mathrm{mg} / \mathrm{kg}$ with biliary drainage group, while, for the $60 \mathrm{mg} / \mathrm{kg}$ with biliary drainage group, $70.5 \%$ of the urine excretion of phallotoxin occurred on Days $0-1$ and $22.1 \%$ on Days 1-2 (Table 4 ).

Table 4. The daily amounts of peptide toxins excreted in urine in beagles with biliary drainage (mg).

\begin{tabular}{|c|c|c|c|c|c|c|}
\hline \multirow[b]{2}{*}{$\begin{array}{l}\text { Time after } \\
\text { Ingestion }\end{array}$} & \multicolumn{2}{|c|}{$\alpha$-Amanitin } & \multicolumn{2}{|c|}{$\beta$-Amanitin } & \multicolumn{2}{|c|}{ Phallacidin } \\
\hline & $\begin{array}{c}20 \mathrm{mg} / \mathrm{kg} \text { with } \\
\text { Biliary } \\
\text { Drainage } \\
\text { Group }\end{array}$ & $\begin{array}{c}60 \mathrm{mg} / \mathrm{kg} \text { with } \\
\text { Biliary } \\
\text { Drainage } \\
\text { Group }\end{array}$ & $\begin{array}{c}20 \mathrm{mg} / \mathrm{kg} \text { with } \\
\text { Biliary } \\
\text { Drainage } \\
\text { Group }\end{array}$ & $\begin{array}{c}60 \mathrm{mg} / \mathrm{kg} \text { with } \\
\text { Biliary } \\
\text { Drainage } \\
\text { Group }\end{array}$ & $\begin{array}{c}20 \mathrm{mg} / \mathrm{kg} \text { with } \\
\text { Biliary } \\
\text { Drainage } \\
\text { Group }\end{array}$ & $\begin{array}{c}60 \mathrm{mg} / \mathrm{kg} \text { with } \\
\text { Biliary } \\
\text { Drainage } \\
\text { Group }\end{array}$ \\
\hline $0-1$ days & $\begin{array}{c}0.0147 \\
(96.3 \%)\end{array}$ & $\begin{array}{c}0.0213 \\
(90.9 \%)\end{array}$ & $\begin{array}{c}0.0050 \\
(93.9 \%)\end{array}$ & $\begin{array}{c}0.0065 \\
(91.4 \%)\end{array}$ & $\begin{array}{c}0.0012 \\
(92.2 \%)\end{array}$ & $\begin{array}{c}0.0017 \\
(70.5 \%)\end{array}$ \\
\hline 1-2 days & $\begin{array}{l}0.0004 \\
(3.7 \%)\end{array}$ & $\begin{array}{l}0.0007 \\
(8.9 \%)\end{array}$ & $\begin{array}{l}0.0005 \\
(6.1 \%)\end{array}$ & $\begin{array}{l}0.0003 \\
(8.6 \%)\end{array}$ & $\begin{array}{l}0.0001 \\
(7.8 \%)\end{array}$ & $\begin{array}{c}0.0005 \\
(22.1 \%)\end{array}$ \\
\hline 2-3 days & $0(0 \%)$ & $\begin{array}{l}0.0001 \\
(0.2 \%)\end{array}$ & $0(0 \%)$ & $0(0 \%)$ & $0(0 \%)$ & $\begin{array}{l}0.0002 \\
(7.5 \%)\end{array}$ \\
\hline 3-4 days & $0(0 \%)$ & $0(0 \%)$ & $0(0 \%)$ & $0(0 \%)$ & $0(0 \%)$ & $0(0 \%)$ \\
\hline Total & $\begin{array}{c}0.0151 \\
(100 \%)\end{array}$ & $\begin{array}{l}0.0222 \\
(100 \%)\end{array}$ & $\begin{array}{c}0.0055 \\
(100 \%)\end{array}$ & $\begin{array}{c}0.0068 \\
(100 \%)\end{array}$ & $\begin{array}{c}0.0014 \\
(100 \%)\end{array}$ & $\begin{array}{l}0.0025 \\
(100 \%)\end{array}$ \\
\hline
\end{tabular}

The data in parentheses are the percentages of peptide toxins excreted daily in bile. 


\subsection{Peptide Toxins in the Bile}

The bile volumes of the experimental groups are presented in Figure S4b. In the $20 \mathrm{mg} / \mathrm{kg}$ with biliary drainage group, $\alpha$-amanitin and $\beta$-amanitin were detected within one day, whereas phallacidin was not detected. In the $60 \mathrm{mg} / \mathrm{kg}$ with biliary drainage group, $\alpha$-amanitin, $\beta$-amanitin, and phallacidin were detected within one day (Table S6). The detection rate of peptide toxins in the bile of beagles is presented in Table S7. In the $20 \mathrm{mg} / \mathrm{kg}$ with biliary drainage group, the accumulated amounts of $\alpha$-amanitin, $\beta$-amanitin, and phallacidin were $0.00007,0.00014$, and $0.00005 \mathrm{mg}$, respectively. In the $60 \mathrm{mg} / \mathrm{kg}$ with biliary drainage group, the corresponding accumulated amounts were $0.00061,0.0012$, and $0.0002 \mathrm{mg}$. In both the 20 and $60 \mathrm{mg} / \mathrm{kg}$ with biliary drainage groups, $100 \%$ of the total bile excretion of alpha-and beta amanitin occurred on Days 0-1. One hundred percent of the total bile excretion of phallacidin occurred on Days $0-1$ in the $20 \mathrm{mg} / \mathrm{kg}$ with biliary drainage group, while for the $60 \mathrm{mg} / \mathrm{kg}$ with biliary drainage group, $81.7 \%$ of the bile excretion of phallotoxin occurred on Days 0-1 and 18.3\% on Days 1-2 (Table 5).

Table 5. The daily amounts of peptide toxins excreted in bile in beagles with biliary drainage (mg).

\begin{tabular}{|c|c|c|c|c|c|c|}
\hline \multirow{2}{*}{$\begin{array}{l}\text { Time after } \\
\text { Ingestion }\end{array}$} & \multicolumn{2}{|c|}{$\alpha$-Amanitin } & \multicolumn{2}{|c|}{$\beta$-Amanitin } & \multicolumn{2}{|c|}{ Phallacidin } \\
\hline & $\begin{array}{c}20 \mathrm{mg} / \mathrm{kg} \\
\text { with Biliary } \\
\text { Drainage } \\
\text { Group }\end{array}$ & $\begin{array}{c}60 \mathrm{mg} / \mathrm{kg} \\
\text { with Biliary } \\
\text { Drainage } \\
\text { Group }\end{array}$ & $\begin{array}{c}20 \mathrm{mg} / \mathrm{kg} \\
\text { with Biliary } \\
\text { Drainage } \\
\text { Group }\end{array}$ & $\begin{array}{c}60 \mathrm{mg} / \mathrm{kg} \\
\text { with Biliary } \\
\text { Drainage } \\
\text { Group }\end{array}$ & $\begin{array}{c}20 \mathrm{mg} / \mathrm{kg} \\
\text { with Biliary } \\
\text { Drainage } \\
\text { Group }\end{array}$ & $\begin{array}{c}60 \mathrm{mg} / \mathrm{kg} \\
\text { with Biliary } \\
\text { Drainage } \\
\text { Group }\end{array}$ \\
\hline $0-1$ days & $\begin{array}{c}0.00007 \\
(100 \%)\end{array}$ & $\begin{array}{l}0.00061 \\
(100 \%)\end{array}$ & $\begin{array}{c}0.00014 \\
(100 \%)\end{array}$ & $\begin{array}{c}0.00122 \\
(100 \%)\end{array}$ & $\begin{array}{c}0.00005 \\
(100 \%)\end{array}$ & $\begin{array}{l}0.00020 \\
(81.7 \%)\end{array}$ \\
\hline 1-2 days & $0(0 \%)$ & $0(0 \%)$ & $0(0 \%)$ & $0(0 \%)$ & $0(0 \%)$ & $\begin{array}{l}0.00004 \\
(18.3 \%)\end{array}$ \\
\hline 2-3 days & $0(0 \%)$ & $0(0 \%)$ & $0(0 \%)$ & $0(0 \%)$ & $0(0 \%)$ & $0(0 \%)$ \\
\hline 3-4 days & $0(0 \%)$ & $0(0 \%)$ & $0(0 \%)$ & $0(0 \%)$ & $0(0 \%)$ & $0(0 \%)$ \\
\hline $\begin{array}{l}\text { Accumulated } \\
\text { amounts }\end{array}$ & $\begin{array}{l}0.00007 \\
(100 \%)\end{array}$ & $\begin{array}{l}0.00061 \\
(100 \%)\end{array}$ & $\begin{array}{l}0.00014 \\
(100 \%)\end{array}$ & $\begin{array}{c}0.00122 \\
(100 \%)\end{array}$ & $\begin{array}{l}0.00005 \\
(100 \%)\end{array}$ & $\begin{array}{l}0.00024 \\
(100 \%)\end{array}$ \\
\hline
\end{tabular}

The data in parentheses are the percentages of peptide toxins excreted daily in bile.

In the $20 \mathrm{mg} / \mathrm{kg}$ with biliary drainage group, $\alpha$-amanitin, $\beta$-amanitin, and phallacidin in the bile accounted for less than $10 \%$ of the total excretion in urine and bile. In the $60 \mathrm{mg} / \mathrm{kg}$ with biliary drainage group, $\alpha$-amanitin, $\beta$-amanitin, and phallacidin in the bile accounted for less than $20 \%$ of the total excretion in urine and bile (Table 6).

Table 6. The ratio of peptide toxins in bile to excretion in urine and bile.

\begin{tabular}{ccc}
\hline Peptide Toxin & $\mathbf{2 0 ~} \mathbf{~ g} / \mathbf{k g}$ with Biliary Drainage Group (\%) & $\mathbf{6 0 ~} \mathbf{~ g /} / \mathbf{k g}$ with Biliary Drainage Group (\%) \\
\hline $\boldsymbol{\alpha}$-Amanitin & $1.3 \pm 2.4$ & $3.1 \pm 2.5$ \\
$\beta$-Amanitin & $5.7 \pm 8.5$ & $15.4 \pm 10.6$ \\
Phallacidin & $4.8 \pm 5.7$ & $9.4 \pm 6.4$ \\
\hline
\end{tabular}

\section{Discussion}

In our previous study, the average concentrations of the different toxins in Amanita exitialis powder were as follows: $\alpha$-amanitin $(1945.4 \pm 91.1) \mathrm{mg} / \mathrm{kg}>\beta$-amanitin $(921.6 \pm 58.8) \mathrm{mg} / \mathrm{kg}>$ phallacidin $(607.2 \pm 40) \mathrm{mg} / \mathrm{kg}>\gamma$-amanitin $(8.3 \pm 0.2) \mathrm{mg} / \mathrm{kg}$ [17]. In the present study, the average concentrations of the different toxins in the same Amanita exitialis powder were as follows: $\alpha$-amanitin $(1966.1 \pm 64.6) \mathrm{mg} / \mathrm{kg}>\beta$-amanitin $(915.1 \pm 76.9) \mathrm{mg} / \mathrm{kg}>$ phallacidin $(602.3 \pm 63.1) \mathrm{mg} / \mathrm{kg}>$ $\gamma$-amanitin $(8.5 \pm 0.2) \mathrm{mg} / \mathrm{kg}$. The quantity of peptide toxins in Amanita exitialis powder did not change in a year. Further, amatoxins cannot be removed or destroyed by cooking due to its thermostability [3]. 
In September 2016, a Sina website reported that seven people in Ning Bo Province were poisoned with dried wild mushroom, which was from Yun Nan Province of China [18]. This suggests that dried wild mushroom ingestion also poses a risk of poisoning with amatoxins.

In our previous study, 20 or $60 \mathrm{mg} / \mathrm{kg}$ Amanita exitialis powder was fed to beagles in starch capsules, and then the beagles were assessed for toxicity signs and biochemical and pathological changes. Vomiting and diarrhea were observed in the beagles at $12-48 \mathrm{~h}$ following Amanita exitialis ingestion. Furthermore, plasma ALT and AST levels, PT, and APTT peaked at $36 \mathrm{~h}$ after Amanita exitialis ingestion. TBIL, DBIL, and ALP levels peaked at $48 \mathrm{~h}$ after Amanita exitialis ingestion. Three dogs died between $24 \mathrm{~h}$ and $72 \mathrm{~h}$ after ingestion of $60 \mathrm{mg} / \mathrm{kg}$ Amanita exitialis. Additionally, histopathological examinations of the liver showed hemorrhagic hepatocyte necrosis [16,17]. In the present study, 20 or $60 \mathrm{mg} / \mathrm{kg}$ Amanita exitialis powder was fed to beagles, on the eighth day after biliary drainage operation. These two studies showed us that, after Amanita exitialis ingestion at the same dose, the dogs with biliary drainage showed less severe toxicity signs than did those without biliary drainage. Dynamic changes in ALT, AST, TBIL, DBIL, and ALP levels, PT, APTT, and INR in beagles in the different experimental groups in the two studies are presented in Figures S5 and S6. The findings suggest that biliary drainage might play a role in Amanita exitialis poisoning.

A plasma kinetics study of amatoxins in humans showed that amatoxins disappeared rapidly from the plasma. Vesconi et al. found amatoxins were detectable in the serum of $65 \%$ patients within $30 \mathrm{~h}$ after ingestion of Amanita phalloides [19]. In another study in patients intoxicated with Amanita phalloides, amatoxins were detectable in the plasma of most patients within $36 \mathrm{~h}$ after ingestion [20]. Our study showed that $\alpha$-amanitin, $\beta$-amanitin, and phallacidin are rapidly absorbed into systemic circulation after Amanita exitialis ingestion. These toxins were rapidly detected (30 $\mathrm{min})$ in plasma and eliminated after Amanita exitialis ingestion. The $\mathrm{T}_{1 / 2}$ of $\alpha$-amanitin and $\beta$-amanitin in the $20 \mathrm{mg} / \mathrm{kg}$ with biliary drainage group was $1.08 \pm 0.76$ and $1.29 \pm 1.07 \mathrm{~h}$, respectively. The corresponding values for the $60 \mathrm{mg} / \mathrm{kg}$ with biliary drainage group were $1.2 \pm 0.58$ and $1.54 \pm 0.71 \mathrm{~h}$, whereas $\mathrm{T}_{1 / 2}$ of phallacidin was $0.62 \pm 0.32 \mathrm{~h}$. The values of $\mathrm{AUC}$, and $\mathrm{C}_{\max }$ in the $60 \mathrm{mg} / \mathrm{kg}$ with biliary drainage group were higher than the respective values in the $20 \mathrm{mg} / \mathrm{kg}$ with biliary drainage group. This indicated that an increase in the external exposure concentration (amatoxins in Amanita exitialis) resulted in a corresponding increase in the internal exposure concentration (amatoxins in plasma). In the $60 \mathrm{mg} / \mathrm{kg}$ with biliary drainage group, the CL/F, $\mathrm{V}_{\mathrm{z}} / \mathrm{F}$, and MRT values for $\alpha$-amanitin and $\beta$-amanitin were significantly different from the respective values for phallacidin. This may be explained by the chemical structures differences between amatoxins (bicyclic octapeptides) and phallotoxins (bicyclic heptapeptides). Unlike in our previous study, in this study, after ingestion of Amanita exitialis at the same dose, the dogs with biliary drainage showed much lower AUC, and $C_{\max }$ values than dogs without biliary drainage [16]. Dynamic changes in plasma amatoxin concentrations among beagles in different experimental groups in the two studies are shown in Figure S7. At the same exposure dose, the dogs with biliary drainage showed much lower internal exposure (area under the curve of amatoxins in plasma) than dogs without biliary drainage [16]. This indicates that bile plays a promoting effect on the intestinal absorption of amatoxins. Biliary drainage caused a more than $70 \%$ reduction in intestinal amatoxin absorption. Similar findings were observed for water-soluble vitamin $B_{12}$ in human and rats. Teo et al. found that bile exclusion caused a $50-60 \%$ reduction in vitamin $B_{12}$ absorption from the intestinal lumen [21]. However, the mechanism by which bile enhances amatoxin absorption is unknown. Bile contains a small amount of bicarbonate compared to those in pancreatic juice, and the quantity of calcium in bile is not greater than that in gastric or pancreatic juice [22]. Therefore, intestinal $\mathrm{pH}$ and calcium ion concentration are probably not relevant to the effect of bile as described [23]. The mechanism by which bile enhances amatoxin absorption may be explained as follows: amatoxins normally bind to intrinsic factors in the stomach. It is reported that the presence of excess free intrinsic factors inhibits the combination of the intrinsic factor-bound amatoxins to the ileal mucosa. The combination of bile acids to free intrinsic factors in the upper intestine might prevent the inhibition that would otherwise occur. Alternatively, bile acids may 
cause dissociation of the amatoxin-intrinsic factor complex at the given receptor site, thus enhancing amatoxin absorption [24-26]. However, there is little evidence to support the above hypothesis.

Previous studies on amatoxins in the urine of patients and beagles showed that amatoxins were detectable in the urine within four days after ingestion $[20,27]$. Our present results showed that amatoxin levels in the urine of beagles with biliary drainage were the highest on Day 1 and persisted in some beagles for up to three days after Amanita exitialis ingestion. The difference in detectable time in the urine can be explained by the low level of internal exposure (amatoxins in the blood). Our results in beagles with biliary drainage also showed that $\alpha$-amanitin, $\beta$-amanitin, and phallacidin in the $0-2$-day urine accounted for more than $90 \%$ (more than $95 \%$ for $\alpha$-amanitin and $\beta$-amanitin) of the total urine excretion. These findings agree with those of our previous studies in dogs without biliary drainage, indicating that biliary drainage had no effect on urine excretion of amatoxins in beagles. Our previous study showed that in the $20 \mathrm{mg} / \mathrm{kg}$ with no biliary drainage group, the accumulated amounts of $\alpha$-amanitin, $\beta$-amanitin, and phallacidin were $0.039,0.0157$, and $0.0037 \mathrm{mg}$, respectively (Table S6). In the $60 \mathrm{mg} / \mathrm{kg}$ with biliary drainage group, the corresponding accumulated amounts were $0.063,0.0264$, and $0.0118 \mathrm{mg}$ (Table S8). At the same exposure dose, the accumulated amounts of peptide toxins in the urine of dogs with biliary drainage were lower than those in the dogs without biliary drainage.

Our present study showed that, in beagles in the biliary drainage groups, $\alpha$-amanitin and $\beta$-amanitin were detected within one day and phallacidin was detected within two days. Busi et al. found low amatoxin concentrations in samples of gastroduodenal fluid obtained by nasogastric aspiration in five patients within $48 \mathrm{~h}$ after ingestion of Amanita phalloides [28]. Jaeger et al. studied 12 patients with Amanita phalloides poisoning and found $\alpha$-amanitin and $\beta$-amanitin in the gastroduodenal fluid of three patients at 34-84 h after ingestion [20]. The difference in detectable time in bile between beagles and patients may be explained by the distinct levels of internal exposure (amatoxins in the blood) between animals and patients. To study amatoxins in bile, bile was collected from animals intravenously injected with labeled amatoxins through tubes tied to the bile duct under general anesthesia and measured. The recovery of radioactivity from the bile was less than a tenth of the injected dose. The result of our study revealed that $\alpha$-amanitin, $\beta$-amanitin, and phallacidin in the bile accounted for less than $20 \%$ of the total excretion in the urine and bile: $<10 \%$ and $<20 \%$ in the 20 and $60 \mathrm{mg} / \mathrm{kg}$ with biliary drainage groups. This, at first, seems a rather small amount. However, it needs to be considered that amatoxins in the bile are secreted by liver cells, which comes from the active toxin of hepatotoxicity. Additionally, hepatocytes were already damaged when amatoxins in the bile were reabsorbed and recirculated through the liver; the amatoxins in the bile may aggravate hepatocyte damage.

Activated charcoal should theoretically adsorb amatoxins that excreted via the bile into the duodenum [29]. Administration of activated charcoal not only adsorbs amatoxins eliminated via the bile, but also those secreted by the intestinal mucosa [8]. Serial charcoal dosing either as a continuous nasogastric drip or pulse dosing with 20-40 g every $3-4 \mathrm{~h}$ (for $24 \mathrm{~h}$ or more) has been advocated by most authors as a relatively noninvasive enterohepatic and enteric dialysis technique [30-32]. However, the relevance between this oral detoxication method and clinical outcome remained unclear [29].

\section{Conclusions}

This study is the first to establish a long-term bile drainage model with beagles in a normal state. This model can be applied to study bile secretion and components in bile-related diseases including amatoxin poisoning. After Amanita exitialis ingestion at the same dose, the beagles with biliary drainage showed less severe toxicity signs and biochemical and pathological changes and much lower internal exposure and accumulated amounts of peptide toxins in the urine than beagles without biliary drainage. Biliary drainage produced a more than $70 \%$ reduction in intestinal amatoxin absorption. This indicates that bile has a promoting effect on intestinal absorption of amatoxins. Amatoxins in the 0-2-day urine accounted for more than $90 \%$ of the total urine excretion, suggesting 
that enhanced amatoxin excretion in the urine may occur within two days after Amanita exitialis ingestion. Although amatoxins in bile accounted for less than $20 \%$ of the total excretion in the urine and bile, biliary drainage may be effective because amatoxins in the bile are the active toxins causing hepatotoxicity and may aggravate hepatocyte damage.

There are some limitations of our present study. First, the use of capsule form instead of toxins in a mushroom matrix could affect the absorption time and results. The disintegration of starch capsule in artificial gastric juice occurred within $15 \mathrm{~min}$. Thus, we thought the effect caused by capsule was within an acceptable level. Second, we did not study the toxicokinetics of virotoxins. Third, we did not detect the contents of amatoxins in feces and organs for the lack of appropriate detection method; therefore, we could not study the distribution and excretion of amatoxins. Finally, bile drainage operation was performed before the beagles ingested Amanita exitialis; however, in practice, bile drainage operation is only conducted after the patient has ingested the poison. Therefore, we did not know the effects of bile drainage in patients poisoned with amatoxins.

\section{Materials and Methods}

\subsection{Animals and Surgical Procedures}

The study was approved by National Institute of Occupational Health and Poison Control review board for animal experiments. Twenty-four male beagles (age, 8-10 months; weight, $10 \pm 1 \mathrm{~kg}$ ) were obtained from Beijing Institute of Xieerxin Biology Resource (Beijing, China). They were randomly divided into four groups of six animals each: control, biliary drainage, and 20 and $60 \mathrm{mg} / \mathrm{kg}$ with biliary drainage groups. The biliary drainage operation was conducted in all groups barring the control group. The dogs were dressed in homemade underwear, coats, and Elizabeth circles for a week to ensure pre-experimental acclimatization (Figure S8a-c). After determining the baseline values for biochemical indicators, the dogs were fasted for $24 \mathrm{~h}$ but received water ad libitum. They were anesthetized by intravenous administration of pentobarbital sodium $(3 \%, 1 \mathrm{~mL} / \mathrm{kg})$ during the surgery. A temperature of $38-39^{\circ} \mathrm{C}$ was maintained with a warming mat. After skin preservation and sterilization, the abdominal cavity was opened through the central abdomen. The abdomen was explored and blunt dissection of the common bile duct was performed (Figure S8d). The common bile duct and its branches were ligated from the intestinal side. A 7.0-Fr drainage catheter (COOK, Bloomington, IN, USA) was percutaneously inserted into the gallbladder, and a medical drainage bag was connected to the drainage catheter coming out of the abdominal cavity. Each opened layer, including the peritoneum, abdominal wall muscle, and skin, was closed with suture. The operative incision was protected with sterile gauze and a bandage, and the dogs were dressed in homemade underwear, coats, and Elizabeth circles. The drainage bag was placed in the pocket of the coat (Figure S8e). After the anesthetic wore off, the dogs were placed in cages, and food and water were provided ad libitum. The operative incision was sterilized with iodophor twice a day until stitches were removed six days after surgery. The drainage bag was replaced every day. On the eighth day after surgery, the 20 and $60 \mathrm{mg} / \mathrm{kg}$ with biliary drainage groups were orally administered a lyophilized powder of Amanita exitialis in starch capsules. In control and bile drainage group, the beagle dogs were fed with empty capsules. Immediately after dosing, the animals were placed in their cages, and food and water were provided ad libitum. Dogs were sacrificed with an overdose of sodium pentobarbital at the end of the experiment. All procedures were performed according to the ethical standards of the National Institutes of Health Guide for Animal Welfare and approved by the Institutional Animal Care and Use Committee (EAWE-2017-005).

\subsection{Chemicals}

lyophilized Amanita exitialis (100 g) was provided by Professor Chen (College of Life Sciences, Hunan Normal University, Changsha, China). The Amanita exitialis powder was stored in a refrigerator at $2-8{ }^{\circ}$ C. $\alpha$-amanitin, $\beta$-amanitin, $\gamma$-amanitin, phallacidin, HPLC-grade water, acetonitrile, 
and ammonium acetate were obtained from Sigma-Aldrich (St. Louis, MO, USA). Normal saline $(0.9 \% \mathrm{NaCl})$, ethyl alcohol, formalin, and hematoxylin and eosin were obtained from Sangon Biotech (Shanghai, China).

\subsection{Peptide Toxins in Amanita exitialis}

An ultra-performance liquid chromatography-electrospray ionization-tandem mass spectrometry (UPLC-ESI-MS/MS) method described previously was used to detect the peptide toxins in Amanita exitialis [16].

\subsection{Toxicology Study}

A toxicology study including an assessment of toxicity signs, a biochemical analysis of the blood, and a histopathological examination were performed as described previously [16].

\subsection{Analysis of Peptide Toxins by UPLC-ESI-MS/MS}

Peptide toxins in blood and urine samples were analyzed as described previously [16]. Bile samples from Days 0-1, Days 1-2, Days 2-3, and Days 3-4 were collected and stored in medical drainage bags and the bile volume was recorded. Plasma and urine samples were stored at $2-8{ }^{\circ} \mathrm{C}$ until analysis for peptide toxins.

\subsubsection{Extraction and Clean Up}

$\alpha$-Amanitin, $\beta$-amanitin, $\gamma$-amanitin, and phallacidin were used as the standard reference materials. Aliquots $(0.2 \mathrm{~mL})$ of bile samples were transferred into $2-\mathrm{mL}$ polypropylene centrifuge tubes in duplicates. Next, $1 \mathrm{~mL}$ of acetonitrile was added to each tube. After vortex-mixing for $1 \mathrm{~min}$, each sample was sonicated for $30 \mathrm{~min}$ and centrifuged at $11,200 \times \mathrm{g}$ for $10 \mathrm{~min}$ at $4{ }^{\circ} \mathrm{C}$. The supernatants were loaded on solid-phase extraction columns (Oasis PRiME HLB, $60 \mathrm{mg}, 3 \mathrm{cc}$ ). The columns were then washed with $3 \mathrm{~mL}$ of methanol/ultrapure water $(v / v: 5 / 95)$. The eluent was evaporated in a stream of nitrogen at room temperature. The dry residue was dissolved in $0.2 \mathrm{~mL}$ of ultrapure water and analyzed by UPLC-ESI-MS/MS.

\subsubsection{UPLC and MS/MS Parameters}

UPLC and MS/MS parameters were as described in our previous study [16]. The limit of detection and limit of quantitation of each toxin in the bile were $0.03 \mathrm{mg} / \mathrm{kg}$ and $0.5 \mathrm{mg} / \mathrm{kg}$, respectively.

\subsection{Toxicokinetic Parameters and Statistical Analysis of Data}

Toxicokinetic parameters were described in our previous study [16]. Measurement data are reported as mean \pm standard deviation values and enumeration data are reported as percentage $(\%)$. Tukey's honest significant difference test was used to identify the mean values that were significantly different between 20 and $60 \mathrm{mg} / \mathrm{kg}$ with biliary drainage groups. SPSS 22.0 (IBM Corporation, Armonk, NY, USA, 2015) was used for statistical analysis. The criterion for statistical significance was $p \leq 0.05$. Except for the biliary drainage operation, the animals and methods in our present study are in accordance with our previously published study [16]. Thus, by directly comparing the data from this study with those from our published studies on Amanita exitialis-exposed beagles without biliary drainage, we can evaluate the impact of biliary drainage on the toxicity and toxicokinetics of Amanita exitialis in beagles.

Supplementary Materials: Supplementary Materials are available online at http:/ /www.mdpi.com/2072-6651/ 10/6/215/s1. Figure S1: Images showing the livers of beagle dogs that died $72 \mathrm{~h}$ in different experimental groups, Figure S2: Representative photomicrographs of H\&E-stained sections of the liver of beagle dogs that died $72 \mathrm{~h}$ in different experimental groups, Figure S3: Representative photomicrographs of H\&E-stained sections of the liver of beagle dogs that died $72 \mathrm{~h}$ in different experimental groups, Figure S4: The urine and bile volumes in different experimental groups, Figure S5: Changes in ALT, AST, TBIL, and DBIL level in beagles in different 
experimental groups, Figure S6: Changes in ALP, PT, APTT and INR values in beagles in different experimental groups, Figure S7: Changes in plasma concentrations of amatoxins in beagles in different experimental groups, Figure S8: (a) Underwear (b) Coat and (c) Elizabeth circle wore in beagles. (d) Common bile duct of beagles (e) Pocket of the coat wore in beagles, Table S1: The amount of peptide toxins in A. exitialis ingested in different experimental groups, Table S2: Dynamic changes in coagulation, hepatic and renal function indicator of beagles in biliary drainage group, Table S3: The detection rate of peptide toxins in blood of beagles (\%), Table S4: The toxin contents in urine of beagles in different experimental groups $(\mu \mathrm{g} / \mathrm{L})$, Table S5: The detection rate of peptide toxins in urine of beagles (\%), Table S6: The toxin concentrations in bile of beagles ingested of Amanita exitialis $(\mu \mathrm{g} / \mathrm{L})$, Table S7: The detection rate of peptide toxins in bile of beagles (\%), Table S8: The daily amounts of peptide toxins excreted in urine in beagles without biliary drainage(mg).

Author Contributions: J.S., H.-S.Z. and C.-Y.S. designed the experiments; J.S., Y.-M.N., H.-S.Z., Y.-T.Z., H.-J.L., Y.Y. and Y.-Z.Z. performed the experiments; P.-B.M., J.Z. and J.-J.L. analyzed the data; and J.S., H.-S. Z. and C.-Y.S. wrote the paper. All authors have read and approved the final manuscript.

Acknowledgments: We are very thankful to Scientific Basic Research Foundation of the Ministry of Science and Technology, China (2015FY111400) and National Nature Science Foundation of China Youth Science Foundation (No.31501814) for providing the necessary fund for this research.

Conflicts of Interest: The authors declare no conflict of interest.

\section{References}

1. Zhou, J.; Yuan, Y.; Lang, N.; Yin, Y.; Sun, C. Analysis of hazard in mushroom poisoning incidents in china mainland. Chin. J. Emerg. Med. 2016, 25, 724-728.

2. Chen, Z.; Zhang, P.; Zhang, Z. Investigation and analysis of 102 mushroom poisoning cases in southern china from 1994 to 2012. Fungal Divers. 2014, 64, 123-131. [CrossRef]

3. Karlson-Stiber, C.; Persson, H. Cytotoxic fungi-An overview. Toxicon 2003, 42, 339-349. [CrossRef]

4. Vetter, J. Toxins of Amanita phalloides. Toxicon 1998, 36, 13-24. [CrossRef]

5. Wieland, T. The toxic peptides from Amanita mushrooms. Int. J. Pept. Protein Res. 1983, 22, $257-276$. [CrossRef] [PubMed]

6. Wieland, T. Interaction of phallotoxins with actin. Adv. Enzyme Regul. 1976, 15, 285-299. [CrossRef]

7. Piqueras, J. Hepatotoxic mushroom poisoning: Diagnosis and management. Mycopathologia 1989, 105, 99-110. [CrossRef] [PubMed]

8. Yilmaz, A.; Gursoy, S.; Varol, O.; Nur, N.; Ozyilkan, E. Emergency room cases of mushroom poisoning. Saudi Med. J. 2006, 27, 858-861. [PubMed]

9. Diaz, J.H. Syndromic diagnosis and management of confirmed mushroom poisonings. Crit. Care Med. 2005, 33, 427-436. [CrossRef] [PubMed]

10. Santi, L.; Maggioli, C.; Mastroroberto, M.; Tufoni, M.; Napoli, L.; Caraceni, P. Acute liver failure caused by Amanita phalloides poisoning. Int. J. Hepatol. 2012, 2012, 487480. [CrossRef] [PubMed]

11. Patowary, B.S. Mushroom poisoning-An overview. J. Coll. Med. Sci. (Nepal) 2010, 6. [CrossRef]

12. Faulstich, H.; Fauser, U. hemodialysis in Amanita phalloides poisoning. Serum levels and excretion of amanitine. Dtsch. Med. Wochenschr. 1973, 98, 2258-2259. [PubMed]

13. Thiel, C.; Thiel, K.; Klingert, W.; Diewold, A.; Scheuermann, K.; Hawerkamp, E.; Lauber, J.; Scheppach, J.; Morgalla, M.H.; Königsrainer, A. The enterohepatic circulation of amanitin: Kinetics and therapeutical implications. Toxicol. Lett. 2011, 203, 142-146. [CrossRef] [PubMed]

14. Madhok, M.; Scalzo, A.J.; Blume, C.M.; Neuschwander-Tetri, B.A.; Weber, J.A.; Thompson, M.W. Amanita bisporigera ingestion: Mistaken identity, dose-related toxicity, and improvement despite severe hepatotoxicity. Pediatr. Emerg. Care 2006, 22, 177-180. [CrossRef] [PubMed]

15. Faulstich, H.; Talas, A.; Wellhöner, H.H. Toxicokinetics of labeled amatoxins in the dog. Arch. Toxicol. 1985, 56, 190-194. [CrossRef] [PubMed]

16. Sun, J.; Niu, Y.-M.; Zhang, Y.-T.; Li, H.-J.; Yin, Y.; Zhang, Y.-Z.; Ma, P.-B.; Zhou, J.; Huang, L.; Zhang, H.-S.; et al. Toxicity and toxicokinetics of Amanita exitialis in beagle dogs. Toxicon 2018, 143, 59-67. [CrossRef] [PubMed]

17. Sun, J.; Sun, C.; Zhang, H.; Niu, Y.; Zhang, Y.; Li, H.; Zhang, Y.; Zhou, J.; Ma, P. Experimental study on acute hepatotoxicity in beagles induced by Amanita exitialis. Chin. J. Emerg. Med. 2016, 25, 1263-1268. 
18. Mengming, Y.; Yan, H. Seven people in Bei Lun were poisoned with dried wild mushroom which was taken from Yun Nan Province of China. Available online: http://nb.sina.com.cn/news/s/2016-09-16/detailifxvyqwa3261144.shtml (accessed on 16 September 2016).

19. Vesconi, S.; Langer, M.; Iapichino, G.; Costantino, D.; Busi, C.; Fiume, L. Therapy of cytotoxic mushroom intoxication. Crit. Care Med. 1985, 13, 402-406. [CrossRef] [PubMed]

20. Jaeger, A.; Jehl, F.; Flesch, F.; Sauder, P.; Kopferschmitt, J. Kinetics of amatoxins in human poisoning: Therapeutic implications. Clin. Toxicol. 1993, 31, 63-80. [CrossRef]

21. Teo, N.H.; Scott, J.M.; Neale, G.; Weir, D.G. Effect of bile on vitamin b12 absorption. Br. Med. J. 1980, 281, 831-833. [CrossRef] [PubMed]

22. Mackenzie, I.L.; Donaldson, R.M., Jr. Effect of divalent cations and $\mathrm{pH}$ on intrinsic factor-mediated attachment of vitamin b 12 to intestinal microvillous membranes. J. Clin. Investig. 1972, 51, 2465-2471. [CrossRef] [PubMed]

23. Grasbeck, R.; Kantero, I.; Siurala, M. Influence of calcium ions on vitamin-b12 absorption in steatorrhoea and pernicious anaemia. Lancet 1959, 1, 234. [CrossRef]

24. Andersen, K.J.; Lippe, G.V.D.; Schjønsby, H. Bile and detergent interaction with the radioassay for vitamin $b$ 12 binders using protein and dextran-covered charcoal. Anal. Biochem. 1976, 74, 488-495. [CrossRef]

25. Parmentier, Y.; Marcoullis, G.; Nicolas, J. The Intraluminal Phase of Vitamin $B_{12}$ Transport in Human; Zagalak, B., Friedrich, W., Eds.; Walter de Gruyter: Berlin, Germany, 1979; pp. 803-806.

26. Mathan, V.I.; Babior, B.M.; Donaldson, R.M., Jr. Kinetics of the attachment of intrinsic factor-bound cobamides to ileal receptors. J. Clin. Investig. 1974, 54, 598-608. [CrossRef] [PubMed]

27. Yilmaz, I.; Ermis, F.; Akata, I.; Kaya, E. A case study: What doses of Amanita phalloides and amatoxins are lethal to humans? Wilderness Environ. Med. 2015, 26, 491-496. [CrossRef] [PubMed]

28. Busi, C.; Fiume, L.; Costantino, D.; Langer, M.; Vesconi, F. Amanita toxins in gastroduodenal fluid of patients poisoned by the mushroom, Amanita phalloides. N. Engl. J. Med. 1979, 300, 800. [PubMed]

29. Chyka, P.A.; Seger, D. Position statement: Single-dose activated charcoal. American academy of Clinical Toxicology; European Association of Poisons Centres and Clinical Toxicologists. J. Toxicol. Clin. Toxicol. 1997, 35, 721-741. [PubMed]

30. Roland, A. Amanita poisoning. Am. J. Med. 1989, 86, 641. [CrossRef]

31. Floersheim, G.L. Treatment of human amatoxin mushroom poisoning. Med. Toxicol. Advers. Drug Exp. 1987, 2, 1-9. [CrossRef]

32. Olson, K.R.; Pond, S.M.; Seward, J.; Healey, K.; Woo, O.F.; Becker, C.E. Amanita phalloides-type mushroom poisoning. West. J. Med. 1982, 137, 282-289. [PubMed] 